ARTICLE

\title{
Analytical sensitivity in education: the power of (auto)biographies in a training- research process involving beginner teachers
}

\author{
Amanda Raquel Rodrigues Pessoal (D) \\ Maria Mikaele da Silva Cavalcante" (D) \\ Wenderson Silva Oliveira"l' (D) \\ Isabel Maria Sabino de Farias" (D)
}

\begin{abstract}
This paper discusses the (auto)biographical perspective as an element of analytical sensitivity in research studies involving teacher training and professional development, focusing on research studies with beginner teachers. The debate that we have raised, based on the discussions held in our Research Group, focuses on a sensitive dimension to help us reflect on the lived experiences and their writings, crossed by the everyday school life. In this sense, we acknowledge (auto)biographical narratives and "written experiences" as powerful tools for understanding the early years of teaching and induction processes.
\end{abstract}

\section{KEYWORDS}

(auto)biography; training-research process; narratives; beginner teachers.

'Instituto Federal do Ceará, Juazeiro do Norte, CE, Brazil.

"Universidade Estadual do Ceará, Fortaleza, CE, Brazil.

"'Rede Municipal de Educação de Sobral, Sobral, CE, Brazil. 


\section{SENSIBILIDADE ANALÍTICA EM EDUCAÇÃO: SOBRE AS POTÊNCIAS DAS (AUTO)BIOGRAFIAS NA PESQUISA- FORMAÇÃO COM PROFESSORAS/ES INICIANTES}

\section{RESUMO}

Este ensaio discute a perspectiva (auto)biográfica como sensibilidade analítica em pesquisas com formação docente e desenvolvimento profissional, direcionando-se, especialmente, à pesquisa com professoras/es iniciantes na carreira. O debate que levantamos, fruto das discussões em nosso grupo de pesquisa, centra-se na dimensão sensível a fim de trazer contribuições para se refletir a respeito das experiências-vividas e de suas escritas, atravessadas pelos cotidianos escolares. Nessa direção, nossa defesa parte de reconhecer narrativas (auto)biográficas e suas "escrevivências" como ferramentas potentes para a compreensão dos primeiros anos da docência e de processos de indução.

PALAVRAS-CHAVE

(auto)biografia; pesquisa-formação; narrativas; professoras/es iniciantes.

\section{SENSIBILIDAD ANALÍTICA EN EDUCACIÓN: SOBRE LOS PODERES DE LAS (AUTO)BIOGRAFÍAS EN LA FORMACIÓN- INVESTIGACIÓN CON PROFESORES PRINCIPIANTES}

\section{RESUMEN}

Este ensayo analiza la perspectiva (auto)biográfica como sensibilidad analítica en la investigación con formación docente y desarrollo profesional, centrándose especialmente en la investigación con docentes principiantes. El debate que hemos planteado, basado en discusiones en nuestro Grupo de Investigación, se centra en la dimensión sensible, con el fin de aportar aportes para reflexionar sobre las vivencias y sus escritos, atravesados por la cotidianidad escolar. En este sentido, nuestra defensa parte de reconocer las narrativas (auto)biográficas y sus escrevivências como poderosas herramientas para comprender los primeros años de los procesos de enseñanza e inducción. 


\section{INTRODUCTION}

In the face of the old

The wrinkles are letters,

Words written in the flesh,

The alphabet of living.

In the face of the young

The freshness of the skin

And the shine of the eyes

Are doubts.

The intertwined hands

Of both,

The old time

Merges with the new,

And the silenced speeches

Explode.

[...]

[From the old to the young - Conceição Evaristo, 2008, p. 51]

Memory and life stories are key elements throughout the works of Conceição Evaristo, writer and poet from Minas Gerais. Her poetics moves in a perspective that mixes writing and life, "or, better said, writing and living" (Evaristo, 2017a, p. 9). In this sense, the writer-artist leads us to think about narratives as inventions, not because they are not committed to what happened, but, because "[...] between the event and the narration of the fact, there is a space in depth, and that's where the invention explodes" (Evaristo, 2017a, p. 11). This paper, in a way, is dedicated to a reflection about the possibilities of the event ${ }^{1}$, since it is moved by the readings that permeated us until we have arrived at these written words, also being part of our experiences as researchers, teachers, inventors, narrators, accountants, and listeners of stories.

We have always tried, in our academic journeys, to merge our experiences with our writings, leaving a lot of ourselves and taking a lot from others whose works we read and with whom we talk. These movements, which happen between the events that our school-university-school journeys provoke, allow us to give new readings and other meanings to the life we lead when conducting research into Education. Similarly, in these encounters, we have also sought to find narratives that question the static vision of a linear and chronological life, singularize what seems

1 In this essay, we use the perception of Foucault (2014) to understand that an event is not, in a certain manner, what happens, but rather, it is in what happens. The event represents "[...] the place of the irrational, the unthinkable, in which does not and cannot enter the mechanics and game of analysis, at least in the form they took within structuralism" (Foucault, 2014, p. 40). 
to be repetitive, evoke plurality, offer uncertain directions for lives full of certainties, poetize our ways of thinking and doing science, and invite us to multiple affections.

In this way, we are in permanent connection with other trajectories, histories, and memories. We create lines of flight and, as we have learned from Deleuze and Guattari (2011), our rhizomes are multiplied and articulated by the diverse knowledge that coexists with us in these encounters. We constantly seek to deterritorialize ourselves, setting ourselves free from the Cartesian and binary legacy we acquired based on the ways of doing science in Modernity. As the rhizome has no structure nor is it fixed, it can be connected to any point at any time. Therefore, we rely on the heterogeneity of life to bring these multiplicities to the debate in our research.

We expand ourselves in an attempt to capture the uniqueness of each word, gesture, and action in an event. As educators, we seek, through the narratives of our peers, to move around within permanent professional training, woven into different webs. As rhizomes, we address new sensibilities thereby perceiving educational institutions and their daily lives as creative and inventive powers, as well as multiple and transforming forces, which are present in the contact between different bodies and subjectivities. Nilda Alves (2008, p. 16), when trying to make sense of the logics of everyday networks, teaches us that "[...] this knowledge and the ways in which it is woven require us to admit that it is necessary to fully dive into other logics to apprehend and understand them".

In this essay, we will discuss (auto)biographical narratives as an element of analytical sensitivity in a training-research process involving beginner teachers. We understand (auto)biographical narratives as the fabulation of everyday experiences that cross, touch, and transform us. Along with this understanding, we borrow the concept of "written experiences", theorized by Conceição Evaristo (2017a), which are the written narratives of these experiences, sewn together by individual and collective relationships, or symbolic representations, thereby providing a powerful possibility of acting upon, building, and transforming research into the professional development of teachers, in particular, the beginning of the teaching career.

We use the term sensitivity intentionally, as we understand that teacher education is full of affection. The moment we launch ourselves as researchers, we are exposed to different situations that cause the most diverse reactions. These are the butterflies in the stomach, hunger, a smile when sharing a snack, impatience, crying, curious looks, odors, pleasures, dialogue with other people, writings, gestures, symbols, and reactions that we produce as social and mobile beings. Among other things, we are invaded by multiple invisible agencies, insurgently affecting our ways of producing research in everyday life, wherever we operate. These are diverse sensations that we can only experience and live when we dive into research-sharing networks built throughout our trajectories and encounters.

Our rhizomes are connected with the support of three articulation lines, geographically located at the Federal University of Rio de Janeiro (Universidade Federal do Rio de Janeiro - UFRJ), the Federal University of Santa Catarina (Universidade Federal de Santa Catarina - UFSC), and the State University of Ceará (Universidade Estadual do Ceará - UECE). Together, these connections form an epistemological network of research that we call Research with beginner teachers: $a$ 
study on professional induction ${ }^{2}$. The proposal considers training-research as a methodological path, as it provides the opportunity for one to meet with himself/herself, an encounter enhanced through (auto)biographical narratives. The reflections of such narratives combine the past and present and, while producing meanings for this union, devise a future through these multiple connections, lines, and readings. In this framework, we use (Certeau, 2014) the concept of "written experiences" (Evaristo, 2017a) to highlight teachers' identities and their bodies, a way of recognizing and valuing knowledge that disrupts "[...] the monocultures of contemporary society in favor of more ecological relationships between different pieces of knowledge, cultures, and forms of expression" (Oliveira and Geraldi, 2010, p. 25).

We believe that by personalizing and humanizing female teachers, we can deepen their formative-educational processes, since "[...] studying how knowledge is woven requires accepting cultural differences without hierarchies, opening up multiple possibilities for the buman act of knowing" (Alves and Garcia, 2016, p. 12). Through lived experiences of everyday life, in different situations occurring inside and outside the educational institutions in which they are inserted, teachers build their networks of knowledge along with many other school practitioners. We learned from Boaventura de Sousa Santos (2002) that the ecology of knowledge is an attempt to overcome the monoculture that permeates scientific knowledge, making room for dialogue between various types of knowledge, so that historically silenced voices emerge and are strengthened to fight for social emancipation. Thus, we make space to highlight this ecological set of knowledge that aids the continuous process of professional training, especially with beginner teachers.

Distance, neutrality, and objectivity are words that permeate several of the research practices. Even though they are not written, it is possible to identify their lines in metanarratives, in generalization, and in the attempt to separate subject from object. When we address (auto)biographies in teacher education, we leave these pillars aside, precisely because we understand we are individuals who are accompanied by the multiple networks built throughout life. When narrating themselves, each teacher becomes aware of their place as subjects and not objects, merges themselves with the story of other people, accesses memories, and listens to their voice. Thus, they start to pay attention to their formative process, abandoning the structural discursive ties that insist on the idea of training for the establishment of professionality.

Nilda Alves (2016) shows us a new way of understanding knowledge in everyday life, understanding it supported by the creation of networks, in which everyday practitioners (Certeau, 2014) are connected by threads and, through these intersections, weave knowledge instead of elaborating it. By dismantling the sense of formulating knowledge - which presupposes that the subject is an empty object

2 This is a network research supported by National Council for Scientific and Technological Development (Conselho Nacional de Desenvolvimento Cientifico e Tecnológico $\mathrm{CNPq}$ ) (2018) that investigates the professional induction of teachers, with regard to the challenges faced by Basic Education teachers in their first years of professional practice in the context of public education networks located in the states of Ceará, Rio de Janeiro, and Santa Catarina. 
- the thought of weaving knowledge in a network allows us to understand that, in the permanent movement inside-outside schools-university-schools, subjects intertwine knowledge and negotiate the perceptions of the world and spin multiple threads that create, in the same way, multiple senses and meanings for life.

Thus, when we resort to life narratives, stories, and writings in teacher training and professional development, we do so because we believe in the strength and potency of the elements that make up these multiple networks. By seeing themselves permanently moving around inside and outside the educational process and their daily lives, teachers broaden their perceptions about education, propose tactics to face and resist the problems that arise, and devise new ways to teach and learn. By spinning and unraveling the web of knowledge, teachers delve into their professional practices, engender new ways of thinking about themselves, the school, and education.

Knowledge networks are rhizomatic, they understand the complexity of knowledge and understand the heterogeneity in the various processes of teaching and learning. Differently from what the official teacher education policy has thought us, which operates to disqualify teacher education (Farias, 2019), we have been striving to bring out the strength of these networks, trying to understand the ways in which "[...] we comprehend how knowledge is created in all areas of human activities - from science to social movements, from the world of labor to social communication" (Alves, 2016, p. 98).

Deleuze and Guattari (2011) teach us that any point of a rhizome can be connected to the other, that is, it is not part of a unilateral and vertical root; on the contrary, the rhizome is spread out and does not follow a hierarchical or homogeneous principle. There are no points, as the authors mention, just lines. By building on the knowledge networks to understand the training process and professional development of beginner teachers, we recognize the complexity of the logics that make up these relationships. The exercise is to try to understand the concept of subject-oriented training and its narratives in the form of "written experiences" as an open map, with intersecting lines. In this sense, we position ourselves in favor of thinking about and writing (auto)biographies in training-research. At the same time that teachers form networks with their students, they are influenced by these networks, which are found in everyday school life, especially the lines we find in the students' experiences.

Our study focuses on the sensitive dimension to help us reflect on the professional development of teachers based on the life experiences of those who are new to the profession, recognizing its subjective dimension and discourses about their training. We understand beginner teachers as those who enter the career for the first time and are in the first five years of the profession (Garcia, 2010). These initial years, according to Nono (2011, p. 19), represent a period of intense learning "[...] and influence not only the permanence of the teacher in the career, but also the type of teacher that the beginner will become". Initiation, for Garcia (1999), is the period in which teachers change from students to professionals, a time marked by tensions and the acquisition of knowledge and professional balance. According to Huberman (2007), career development is a process permeated by regressions and discontinuities. With regard to the period of professional insertion, in general, it is a moment marked by anxiety, insecurities, fears, discoveries, and learning, as the 
knowledge acquired and their ability to articulate these are evidenced and judged, making the teaching initiation process especially important. It is also in this initial period that teachers begin to establish their personal and professional identities, learning to teach by teaching.

We bring to a debate the conceptual approach to the theme outlined so far, the result of reflections made during the Collective Guidance Meetings (Encontros Coletivos de Orientação - ECO) held by the Education, School Culture, and Society Research Group (Grupo de Pesquisa Educação, Cultura Escolar e Sociedade - EDUCAS) ${ }^{3}$. Aware of the limits of this writing, we focus this discussion on promoting teacher education driven by an analytical sensitivity that is based on (auto)biographical narratives and the potential of their writings to monitor, build on, and understand the processes of professional teacher development, in particular, during the profession initiation process. Therefore, we hope to encourage a debate about the methodological possibilities when conducting research with beginner teachers and about the multiple uses of narratives in (self)training investigation.

\section{TEACHER TRAINING AND (AUTO)BIOGRAPHIES: APPROACHES}

In our research, we understood that the main purposes of (auto)biography is to reflect on life stories, one's own stories and the stories of other people. This research focuses on the authors telling their stories and experiences. In other words, "[...] to understand the relationship between the subject, their trajectory, and the scheme of concepts that are produced from the narratives and reports of experiences that each one goes through throughout their formative process" (Silva, 2020, p. 6). Nóvoa and Finger (2014) understand that this capacity for reflection facilitates the development of a holistic sociology of training, allowing training to be tailored to the specificity of each person. Thus, we can understand that the training process centered on self-understanding is linked to its reflexive condition and to the multiplicity of senses and meanings that the subject is able to translate based on his/her experience. It involves, therefore, a movement to turn to oneself, seeking to establish relationships between the lived experience and their daily lives for the production of a new being.

Although a subject's trajectory can be determined by society and culture, events and encounters are largely unpredictable, which give meaning to the interpretive aspects of a narrative, a moment in which the narrator himself gives a new meaning to the lived experience. This suggests that it is not possible to anticipate the weight

3 The ECO is characterized as a unifying activity, monitoring and sharing the training and research action developed within the scope of the EDUCAS research group, linked to the Postgraduate Degree in Education from the UECE, led by Professor Isabel Maria Sabino de Farias. In it, university and Basic Education teachers, doctoral students, masters, undergraduates, and other interested parties meet monthly to discuss their research, study, and debate topics related to education and that are of collective interest to its members. For more on this experience, see: Barros et al., 2020. 
that experiences will have during the trajectory of each subject, mainly because it is not possible to know how the experiences are taken by the subject, except for the production of its own narrative, in which the subject turns to him/herself and through it reconstructs what has been lived in a new time. (Silva, 2020, p. 4)

For Larrosa (2011), an experience is what happens to me. Experience presupposes an event, something that is external to the self. As we saw in Foucault (2014), an event is expressed in what happens, therefore, thinking about the event to understand what happens to us is to think about what goes through us, it shifts our perceptions of the world to what happens to us, and not to what happens around us. And, beyond that, thinking about how this involves us, displaces us, and deterritorializes us. In this sense, we understand that teaching training through the lenses of (auto)biography is also self-formative, as it is not limited to an individual root-system, but includes collective relationships that stem from social and cultural relationships built throughout life.

Therefore, we postulate the argument that training has no territory. We realize, based on our research-and-experiences, that it is not only concentrated on an inert set of plans and actions, but opens up possibilities for the connection of several lines. As we argued at the beginning of this text, it is rhizomatic, experiential, and is always in constant motion. In the words of Deleuze and Guattari (2011, p. 25-26),

Every rhizome comprehend lines of segmentation according to which it is stratified, territorialized, organized, meant, attributed, etc.; but it also understands lines of deterritorialization along which it runs uninterruptedly. There is a rupture in the rhizome every time that segmental lines explode into a line of flight, but the line of flight is part of the rhizome. These lines keep referring to each other. That is why you cannot rely on a dualism or a dichotomy, not even in the rudimentary form of good and bad.

When we perceive training as rhizomatic, we understand that experiences will always be heterogeneous and, in this perspective, we no longer think about it, but rather along with it, putting ourselves in constant search for ourselves, as mentioned by Ferraço (2003), a movement of prey and hunter. In this sense, studying/researching/ thinking along with eliminates today's canonical code of separating the subject from the object, breaks the logic of the dominant over the dominated, fractures the logic of power, which elects a single and unilateral history. Doing with is a way of looking in the rearview mirror of our history to perceive the various yarns of the web we weave when we are formed and those we weave when we form so many others that we meet during our journey. In this sense, our experience connects the past to the present to discern possibilities for the future in the teaching trajectory, since we live intensely in the heterogeneity of these experiences, constantly giving them meaning.

Still in Larrosa (2011, p. 6), we learn that "[...] the experience is a back and forth movement", a permanent movement, as we usually say. It is going forth because it is outside of us, it is like moving away from ourselves, from the inside out, that goes towards the event. It is going back because the experience affects us and produces effects and feelings in our subjectivity. From this perspective, living and to experiencing 
are synonyms. The memories of what happens to me in the course of my life, even if ephemeral, mobilize the event character that happens with the experience. The experiences, with their deep marks of everyday life, mend a single story, fable, dismantle chronologies and linearities, start the writing of an open map that slides through memory, life history, emotions, and feelings that displace the Cartesian space-time.

The experience as a transforming power is strongly linked to learning, it is formative by its reflexive and symbolic character, established throughout life. In an orchestrated polyphony of asynchronous bars, the experience as learning exposes the visceral character of what has been experienced, that is, we feel the multiple crossings of everyday singularities in our own skin; and when we go through the other, we also feel it in our own skin. It is like diving into deeper inside, as Nilda Alves (2008) teaches us. We believe that it is only possible to understand the formative logics if we fully immerse ourselves in it. By both living and experiencing, we can immerse ourselves in the web we weave throughout life, being influenced by this movement and its repercussions. We go deeper into this movement to understand our formation and the elaboration of our subjectivity.

Marie Christine Josso $(1999 ; 2006)$ points out that formative experiences have a strong relationship with the different ties and knots acquired throughout life, whether personal or professional. These can establish enriching or threatening links for the establishment of their existentiality, but all of them denote a meaning within a formative perspective. Thus, when thinking along with experiences and the incarnations they leave in the writings of life (or "written experiences"), we call these ties and knots to a singular narrative that points to the collectivity, because they show the visceralities, "[...] the place of enunciation of a collective self, someone who evokes the story of a shared 'we' through their own narrative and voice" (Soares and Machado, 2017, p. 207). We believe that it is a fundamental dimension to understand the knowledge projects that involve training in the course of life. The "we" tells a lot about the "self" and about the schools practiced by each teacher who are in them.

For Josso (2007), the narrations of life stories contribute to a transformation of oneself. After all, we are beings with biological and psychosocial links, we are singular and plural at the same time, constituted with individual and collective dimensions. Recognizing these characteristics is addressing the power that permeates the human experiences of adults as learners, who reflect on and transform their actions. As Nóvoa and Finger (2014) teach us, thinking from the (auto)biographical perspective of training (lived experiences) is a task that requires a deep respect for people's lived experiences. After all, this heterogeneous procedural nature allows us to investigate not only these processes, but also the sub-processes that make up the backstage of training.

Teacher training is at the heart of the educational process, because teachers are professionals who experience various dilemmas in their work contexts. After all, they deal with the complexity of the teaching and learning process. This process requires a constant search for understanding themselves, other people, and the flows in which they are inserted. It also implies a continuous analysis of their work and professional practice. For this reason, the (auto)biographical perspective is constituted as a unique methodological possibility, especially in the field of training, which is articulated with the personal life-experience and its social and cultural contexts. 
When intertwined, these contexts give rise to reflective dialogs that change the way of being and acting of those who participate in them.

Thinking about and acting upon the relationships between (auto)biographical narratives and teacher education are not just about making memories re-emerge, but also reconstituting history and memories marked with reflections and meanings gathered over the years and that also permeate bodily memories. Far from homogenizing rhetoric, these relationships will show the microcosms of the schools we have been through, the smell, the noises, the faces of children and teenagers, the primary teachers, the university chairs, and various other fragments that get mixed up with the inventiveness of the narrative. These memories bring humans to the center of our reflections and, by writing the biography of life, we slow down the chronology of time that insists on accelerating everyday life and we strengthen aspects that gave meaning to our existence in each cycle of our life (Bragança, 2012).

Each person experiences and signifies their past in unique ways. Therefore, a narrative is not intended to make a trustworthy reconstruction of the past - and, perhaps, it is not even possible, considering that, in order to bring out the past, it is necessary to resort to memory, which is, in its essence, flawed and fragmented, - but rather perceiving, through memory and elaboration of the narrative, whether written or spoken, the reflections that arise and can re-signify present realities and reverberate in future experiences. And when memory fails? - Conceição Evaristo (2017a) asks us. Inventiveness arises - the poetess answers. Certeau (2014, p. 142) tells us that a report is not just about adjusting to a possible reality, narrating what actually happened, "[...] on the contrary, the narrated story creates a space of fiction. It moves away from the 'real". Thus, when teachers start addressing the "written experiences" of their (auto)biographies, they dismantle chronology and linearity, start writing an open map that slides through memory, life history, emotions, and feelings that displace the Cartesian time-space. By addressing their "written experiences", they transgress their own memories, because they question the canons that separate body from mind. A report brings life stories to the bodies and the bodies to life stories, that is, there is no inseparability, on the contrary, narratives with "written experiences" are full of marks suffered on the bodies and are in constant movement to break homogeneous silences and violent hierarchies (Ribeiro, 2019). In short, a formative activity.

Therefore, we consider that it is essential to perceive (auto)biographies as a powerful element of analytical sensitivity when conducting research along with teachers, in articulation with training. Through these theoretical-analytical-epistemological lenses, we recognize and understand subjective knowledge that escapes formality, by realizing that people put it into practice as something relevant for establishing the teaching profession; a biographical knowledge directly associated with the temporal dimension of human experience and action (Delory-Momberger, 2006).

\section{THINKING ALONG WITH NARRATIVES AND WITH LIFE STORIES}

From what I heard, I picked up these stories. I asked nothing. An untimely intervention can threaten the naturalness of the voice flow of the teller. I accept 
the stories they tell me. From my listening, I leave only gratitude and avoid the installation of any suspicion. So I walk through voices. I often hear speeches from those who don't even see the body. Nothing surprises me concerning the invisible that I harvest. I know that life cannot be seen with the naked eye alone. (Evaristo, 2017b, p. 17)

A lot was said about narrative. It is a common word in many academic writings and holds many meanings. In this essay, we understand narrative as the act/ action of telling a story (Paiva,2008), which can be a real or fictitious event report, a series of sequenced events (or not), an event report, non-logical, non-chronological events, and so on. Pérez (2003, p. 101) teaches us that "[...] the act of narrating your story is an act of knowledge". As we narrate our life stories, according to the author, we reinvent ourselves, produce new meanings to events, revisit the marks inscribed on our bodies. For Galvão (2005), narratives are based on the overlap between Story, Discourse, and Meaning.

Story - covers the characters involved in certain events, in a certain space and time, and allows for a first interpretation of what is told; Discourse - specific way in which any story is presented; Meaning - a second-level interpretation that the listener/reader/viewer obtains from the interrelationship of the story and the respective discourse. (Galvão, 2005, p. 328)

We understand that narrative and story are not synonymous words. For us, a narrative is a set of knowledge that weaves a story. In our research, we also use narratives as "written experiences", memories that report individual and collective stories and experiences. We understand that this orality will compose a flux of different events that transpose the body and, based on them, the story is invented. A report, according to Certeau (2014, p. 144), “[...] does not express a practice. It is not about describing a move. It performs it". When we realize that a report provokes movement, we can understand that the lived experience takes place there. In other words, from the teacher training perspective, each subject, by having a report, narrates themselves, when triggering this lived-experience, displacing the meaning of the stories being told about training, opening the field for crossings and pluralities, and fracturing the idea of a single story and also a singular narrative.

For Clandinin and Connelly (2015), researchers who use narratives to do their work face tensions at the borders of what the authors call dominant narrative (more traditional research approach) and narrative thinking (narrative research approach). In this sense, the technical rationality that drives scientific thinking inherited in current times tends to question research modalities that value people's modes of subjectivation. The approach of narrative thinking, as proposed, invites researchers to think about and (re)tell life stories based on the understanding that the ways of living, the temporalities, the practices, and the processes will be under permanent negotiation by the practitioners of daily life (Certeau, 2014).

People and their actions are in transit, the certainties are temporary and will shift, contexts will no longer be universal, but endowed with singularity, permeated 
by plurality. Thinking narratively requires a paradigm shift in the understanding of the study, in the ways of dealing with those who share their stories with us, trying to overcome the idea of objectivity and the determinant search for Cartesian empirical results; from this perspective, when we leave metanarratives aside and think about training-research along with teachers based on their narratives,

[...] we need to think about possibilities of speeches that can record the thoughts and words that spill over the walls and corridors of schools and that are not always said. Discourses that need to include other discourses, alternatives, and that always bet on their own explanations. Discourses that lie in wait, hoping to capture micro-differences that mark the subtleties of speech, gestures, and images that inhabit everyday life. Discourses that attempt to translate the languages and ways of being and existing of everyday subjects in whose bodies we find the marks of uses and transgressions. Discourses that have distracted eyes that cease to be many other things besides those that have been made visible. Discourses that, despite our freezing gaze, need to deal with shifting identities, hybridisms. Discourses that, however alive they may seem in the eyes of readers, are still far from capturing the full intensity of everyday life. The everyday life pulses much more strongly than any analysis that we do "along with" them. (Ferraço, 2003, p. 172-173)

It is a unique fabric of subjectivities, composers of experience. The lines of flight become entangled for the understanding, interpretation, and reflection on what has been lived. Clandinin and Connelly (2015), when elucidating us to think narratively in research based on the differences between formalistic researchers and narrative researchers, explain that the narrative research is not intended to exalt theory, but to use life experience as a transforming potential that has an element of reflection in theory. It is a "[...] conversation between theory and life, or, at least, between theory and the life stories contained in the research" (Clandinin and Connelly, 2015, p. 75). This movement of being able to learn and apprehend the lines of flight, and also learn along with the lines of flight, concerning narrative thinking is dear to us. Nilda Alves (2014) teaches us that the existence of a multiplicity of educational networks provides us with complex understandings of the world and actions developed professionally and, thus, we need to understand them in their particularities, trying to understand the relationships they rhizomatically establish one with the other. And how can we, therefore, break the metanarratives so that our research is woven into rhizomes?

Over and over again, in conversations, we rely on it as a research practice to enhance the narratives that circulate our encounters with the people who research along with us. And conversations also allow us to establish other lines of flight concerning narrative thinking, by making use of this perspective on research-training. In addition to establishing a dialogue with theories, "[...] the meeting and conversations allow for additional learning, based on other logics and knowledge in teacher education" (Gonçalves, Rodrigues and Garcia,2018, p. 127). In this understanding, conversations are the space-time of dialogic interactions and negotiations of meanings that question hegemonic meanings by producing new meanings for the subjects' knowledge. 
We need narratives that contribute to an amplified understanding of what the social reality in which we are living is and can be, hidden and made invisible to the "naked eye" by the norms and regulations of modern science, of the hierarchy it establishes between theory and practice, and the texts produced according to such norms. (Oliveira and Geraldi, 2010, p. 23)

Conversations, as possible paths for us to enter and understand the potential of (auto)biographies, show themselves as inventive and very informative."We understand conversation as a summoning of different knowledge in a non-hierarchical, but ecological way, provoking an ecology of differences that overshadows the idea of uthorship" (Süssekind and Pellegrini, 2018, p. 145). As we said at the beginning of this text, we mix our experiences with the experiences of the people with whom we research, in a movement of prey and hunter. As mentioned by Ferraço (2003), we learned to multiply the meanings that the discourses have to us. Consequently, we need to consider other movements that go beyond the discourses as narratives. Therefore, we also register sounds, images, body movements, objects, and many other things that unfold beyond these spoken words.

With that, the immersions we make in life stories can be grasped (and apprehended) more effectively, because they transcend the listening experience. We are also traversed in everyday events, our lives and experiences intertwine with many others and produce senses and meanings that also shape us. As we learned from Conceição Evaristo (2017b) that life cannot be seen only with the naked eye, therefore, we strive to pluralize what we call methodology, drinking from different sources so that we can get closer to our interlocutors and entangle in them. With that, we are required to broaden the sources we use for our knowledge networks. In this aspect, the sources we seek are in the most diverse places and this requires us to take a variety of actions to apprehend them.

Based on the narratives, as researchers, we will build what Delory-Momberger (2012) calls entanglement, a process that transforms what was told into an organized story that brings the idea of the whole (configuration) - a synthesis of the various elements, such as agents, goals, means, interactions, circumstances, results; it would be a synthesis of the heterogeneous that, in the end, will become a significant and meaningful element, producing effects on what it reports. Thus, according to the author, we have to dive into the uniqueness of the subject, taking the opportunity to use the openings that are made available during the biographization process (Delory-Momberger, 2016), which can have different mental, behavioral, and gestural manifestations.

When thinking about (auto)biography as an element of analytical sensitivity, we put different structures aside so that we can dive into everyday life, as stated by Nilda Alves (2008). Therefore, we did not use structured questionnaires, objective answers, structural analysis, totalities, and other categorizations that restrict people. Instead, we wanted to think about microcosms that consider the potencies of the life led. For us, sensitivity is the ability to feel. The action of feeling takes several directions that we can understand as affections manifested in the understanding of oneself within a network of meanings and senses that are woven throughout each person's history. In our research, 
we are constantly trying to apprehend a fleeting object. Therefore, we consider that we need to be open to crossings so that our sensations describe what goes on in the schools and in the professional lives of teachers who are beginning their careers. This does not mean that we will refute what was done, but, as an open map, the research studies - including this one - need to be free from restrictions and from the elements that reduce the speech and writing of those who collaborate with us.

\section{BEGINNER TEACHERS AND PROFESSIONAL DEVELOPMENT: THE IMPORTANCE OF WRITING ABOUT THE LIVED EXPERIENCE}

We consider teacher professional development to be the progress teachers experience during their professional career, consisting of various phases and lived experiences accumulated during their lifetime. When we refer to professional development, we allude, first of all, to a person who feels and goes through situations that will directly interfere with their thinking and acting as a teacher. In this way, in our research studies, we think of (auto)biography as a formative possibility to emphasize the subject and value the repertoire built based on these lived experiences, as we have argued several times throughout this text.

In our research, we focus on teachers who are beginning their careers, trying to understand how they act and react in relation to the difficulties of teaching and its affections in the first years of professional practice. For this, we assume follow-up actions for beginner teachers that favor the learning of the profession, from a perspective that contributes to their insertion in teaching, actions identified in the literature as professional induction (Cruz, Farias and Hobold, 2020). For us, induction is the investment of intentional, systematic, and institutionalized training around beginner teachers during their professional insertion (Nascimento, Flores and Xavier, 2019, p. 155).

Institutionalized actions of professional teaching induction ${ }^{4}$ are important to offer conditions for teachers to establish their professional trajectories and share their concerns, doubts, uncertainties, and other affections that are inherent to the profession. Therefore, in our conversations, we discuss the everyday knowledge, understanding their motivations as heterogeneous, taking into account the professional life cycles and the training needs of each teacher (Ferreira and Reali, 2005). We awaken our senses as researchers to think along with teachers about their training, through their life stories. In this sense, Delory-Mombeger (2006), when highlighting training trends through life stories, identifies in the narrative of the self, through the production of its story, an important aspect to think about the formative dimension of the life experience. Josso (2007), in turn, points out that these narratives reveal multiple forms and meanings of existentiality, and through them, it is possible to establish social and cultural relationships inherent to the contexts of professional and personal life.

4 Alarcão and Roldão (2014) clarify that we should not confuse professional induction with the probationary period, therefore, for the authors, it is about thinking about training in a work context, which will link initial training to continuing education. 
From both perspectives, we identified the lines that reveal the subject's transforming potencies by being immersed in the sensibilities of thinking about their life story and also the other person's life story. Therefore, the analytical sensitivity of (auto)biography has a possibility and a path to be considered, considering that it focuses precisely on lived experiences and ecological knowledge that are intertwined with subjectivities and formulate teachers' identities. These identities being built constitute provisional configurations (Bragança, 2011), express themselves as procedural and changeable, are constantly re-signified, taking on new formats in relation to the image of oneself and the way of being in the world. For the author, training depends precisely on how something a person has gone through in life is transformed into experience. For us, the inseparability between life and experience turns these identities into identities that have no territory and that are rhizomatic.

Therefore, narrating, writing, and reflecting on the professional path is a training exercise that helps in teacher development, as it prompts the subject to [re] think about their practices, fable new ways of doing school, and turn their gaze to their daily lives. In this sense, (auto)biographical research is expressed as a unique opportunity to think about and conduct research, train the one who carries out the research and the study subject, considering the body of knowledge that is mobilized during this process. Thus, by turning our eyes to the experiences of beginner teachers, especially in Basic Education, we intent to formulate, along with them, strategies so that when they start the profession, they are able to reflect on themselves and others who transit and exist through/in schools. This network collaboration gives meaning to several other networks that, based on school education, allow teachers to tell about the experiences that permeate the beginning of the career and, at the same time, be sensitive listeners to those who face similar moments in the profession.

Our readings and lived experiences concerning research allow us to understand that the beginning of the teaching profession is a moment of adaptation, with intense learning and experimentation. It is a time that is permeated by a mixture of feelings: being officially recognized as a professional in the field, the experience of having a class of students for the first time, the reality shock, and the relationship with their peers. A real stage of survival and constant groping (Huberman, 2007). It is at the beginning of their careers that teachers express their main difficulties, considering that this moment is marked by being inserted into a new reality, of a professional nature, which requires permanent action and pedagogical intervention in different realities. Beginner teachers require special attention in the training process, prompting them to think about their daily practice to become a professional.

Thus, we believe that understanding and enhancing the writing about the lived experiences is fundamental. After all, being a teacher/beginner teacher means being in a professional place of vulnerability, where narrating, talking, writing, observing, and reflecting are actions that help to think about the practice and profession in its entirety. Teachers at the beginning of their careers need to be accepted, listened, and need to share. This can be ensured through research-training and, above all, through "written experiences". This theoretical-analytical-epistemological perspective allows us to recognize and understand the different knowledge and resistances that surround the teaching universe and that escape formality. In our 
research, we exercise attentive listening and commitment to differences. We dive into a field of formative possibilities through the stories we hear, of struggle, overcoming, prejudice, discrimination, affection, sadness, and happiness. These are stories of resistance that allow us to "write about our experiences" as new pages in teacher education books. They form stories that are attentive to the times/places of speech (Ribeiro, 2019), which seek to break with silences, hierarchies, and oppressions.

We rely on the writing of these experiences, or "written experiences", as an analytical tool endowed with sensitivity. We understand that, in the process of professional teaching induction, the trajectories will be rhizomatically mixed, opening space for understanding the entanglements of teacher education, while understanding our training. When thinking about the paths, teachers can discern their knowledge, and multiply and share it with their peers, enhancing the encounters and the daily school life as inexhaustible sources of training and professional development.

"Written experiences" are also a way to break with the silence and erasure of social markers, such as race, gender, sexuality, disabilities, and other aspects. We intend that the narratives of beginner teachers also address these experiences and that they write about them, making a commitment to the demarginalization of certain bodies, the decolonization of the ways of doing research, and the need to promote justice social for those who exist and resist in the most diverse educational spaces. If researchers with narratives are strongly (auto)biographical, as stated by Clandinin and Connelly (2015),

[...] writing about our experiences means, in this sense, to tell stories that are absolutely private, but that refer to other collective experiences, since it is understood that there is a common constituent between the author and the protagonist, whether by means of characteristics shared through social markers, or by the lived experience, even if lived from different positions. (Soares and Machado, 2017, p. 206).

In the sense of "written experiences", the experience of the Self is directly connected with the experience of the Other, without subordinating it, dominating it, ranking it, or categorizing it. The act of "writing about experiences" unfolds the narrative and (auto)biographical research by combining the personal and social terms, the past, the present and the future, the time and the spaces (Clandinin and Connelly, 2015) with the differences ${ }^{5}$. Our use of these tools helps us to understand the subjective aspects that make up the professional development of beginner teachers. In this aspect, when we "write about experiences", we do so because we believe that subjects displace the totalization and make room for us to see the

5 When we refer to the Other or the construction of Otherness, we speak of power relations between individuals, without considering, however, that the power comes from a specific place. We think about how the subject creates the object, exoticizing it, making it different. In this respect, we start with Avtar Brah (2006) to understand that what we call difference starts from the fabric of social relations, thinking of difference as a constitution and organization systematized through economic, cultural and political discourses, in addition to institutional practices. One group mobilizes this concept when dealing with the genealogy of collective experiences, exploring what would be "us" and "them" as a way of differentiation, always imbued with power. Here, we evoke difference as a potentiality, in order to break the historically systematized exclusions in Brazilian social relations. 
microcosms of their daily lives. In these ecological relationships, we broaden our understanding of narrative possibilities and the life stories themselves. We started to pay attention to the time-space in which research-training is developed, in the images, face expressions while speaking, tone of voice, surrounding smells, clothes, photographs that marked important moments. It is the invitation to "[...] discover/ invent new ways of seeing/reading/hearing/feeling the world and narrating it and the different actions/pieces of knowledge/values and emotions that circulate and dialogue with it" (Oliveira and Geraldi, 2010, p. 19).

Thinking along with narratives and with life stories calls us to immerse ourselves in teaching processes that go beyond what is spoken while the voice recorders are on. We discover the richness of dialogues and actions that escape the liturgies set up for research - such as recordings, notebooks, or photographs made by us. When diving into life stories through narratives, we try to be careful not to reduce conversations into qualitative reports, we make an effort for these conversations to be treated as main tools for thinking about educational practices and how the knowledge of beginner teachers is articulated in them, how webs are weaved in the different contexts researched by us.

We narrate life and literatize science, as Nilda Alves (2008) teaches us. When we discuss the life stories and the use of conversations in "writing about experiences", we reinforce these actions as analytical sensibilities that put the structures aside and allow us to delve into the daily lives of the beginner teachers who walk along with us in a training-research process. As an element of analytical sensitivity, writing a(n) (auto)biography suggests an understanding of the narratives as a possibility of making the voice, experiences, learning, perceptions, and feelings of teachers visible. It also means to say that this is a powerful alternative to be used with teachers who are experiencing their first years of teaching, as it gives rise to narratives in a difficult scenario in which they tend to be underestimated and not listened (Garcia, 1999). When talking about themselves, beginner teachers produce new meanings for their experiences, give new meaning to their learning, and reflect on their practice. It is a process that encourages training and leads them to rethink concepts and actions.

\section{FINAL CONSIDERATIONS IN FAVOR OF NARRATIVES}

In this writing, we seek to outline reflective elements on the importance of (auto)biographical narratives as an element of analytical sensitivity when conducting research with beginner teachers in induction processes. Our defense of narratives is based on an understanding that adopts a scientific thinking that ruptures the subject-object distancing and brings us closer to sensitive relationships, capable of affecting the human condition of teachers and transforming them into moments when they can encounter themselves and others. In this sense, (auto)biographies are sources that bring sensitivity, empathy, and learning to those who participate in the research collective.

We want to make formative lived experiences plural, trying to apprehend what goes unnoticed to inattentive ears. This invites us to consider binarism, opening 
the way for multiplicity, which is why we treat teacher education as rhizomatic in our research. Thus, we understand we have to let ourselves be taken by the daily life that surround us and, with the support of these contingencies, understand that we need to be "[...] open and ready to incorporate, interrogate, and analyze, seeking to understand everything that comes to us, from these 'spacetimes', in their very different events, through all our senses" in order to research about daily life (Andrade, Caldas and Alves, 2019, p. 24). This movement also includes understanding the ongoing differences in everyday schools.

We are open, as researchers and teachers, to the lived experiences that come to us; willing to listen, smell, touch, among other things, to be taken by the multiple invisible assemblages and rebellious narratives that affect the ways of weaving formation in school routines. In this aspect, the work with (auto)biographical narratives and "written experiences" of teachers invites us to question the constituted truths and the theories that are willing to investigate these truths, so that the truth can be assembled. This leads us to think about the need to frequently question the knowledge we acquire about teacher training and the analytical tools we use to understand it. In this way, we come to understand formation as a process of becoming, which is always in continuity and takes place in multiplicities and events.

We bet on the narratives experienced through (auto)biographies and "written experiences" because we believe that they are potentialities in the research we develop with beginner teachers. Narrating life, "transforming it into literature" and "writing it" are movements to break with anonymity by giving voice, time, color, expression, and flesh to the subjects with whom we research. It is realizing that, for us, narratives are beyond the spoken words, they are a challenge that prompts us to think of ways of research that are committed to a social transformation, committed to eliminating the academic jargon to align themselves with textual simplicity, with the simplicity of dialogue when talking.

The reflections outlined here are the result of our discussions in the collective guidelines, in the networks that we share in the research group. They reflect the resistance movements that we make to the regulatory prescriptions that aim to subject subjects/teachers at the beginning of their professional training. If, on the one hand, we understand the beginning of the teaching career as a period of uncertainties, fears, and insecurities; on the other hand, we defend the argument that this period is also the moment when teachers discover themselves, weave their first threads, and intertwine them with various plots that go through the daily lives of schools.

Thus, we invent new ways of thinking about research-training with beginner teachers, ways that value places of speech, rhizomes, networks, ecological knowledge and, therefore, inventiveness. We value teacher resistance, practices, and theories that are manifested in the actions and reactions of these subjects in everyday school life; everyday lives that write experiences in (auto)biographical narratives, showing the incarnations of lived experiences full of multiplicities. The induction processes lead teachers to reflect on their practices, on the limits and possibilities of their practices. Therefore, we believe in the strength and power of our productions, because they echo events and voices that are often present in anonymity.

Therefore, we finish this paper by questioning the idea that, in order to research with beginner teachers and their (auto)biographical narratives, we have to 
multiply the lines, apprehend bodily vibrations. By turning our eyes to the (auto) biographical narratives of teachers and their daily lives, we are interested in what escapes the character of being official, we are committed to networks, knowledge, and practices, to movements inside and outside schools-university-schools. With that, we hope that this open map will give rise to new lines of flight, other conversations, and renewed problematizations.

\section{REFERENCES}

ALARCÃO, I.; ROLDÃO, M. C. Um passo importante no desenvolvimento profissional dos professores: o ano de indução. Revista Brasileira de Pesquisa sobre Formação Docente, Belo Horizonte, v. 6, n. 11, p. 109-126, 2014. Available at: https:// revformacaodocente.com.br/index.php/rbpfp/article/view/108. Accessed on: Dec. 8,2021. ALVES, N. Decifrando o pergaminho: os cotidianos das escolas nas lógicas das redes cotidianas. In: OLIVEIRA, I. B.; ALVES, N. G. Pesquisa nos/dos/com os cotidianos das escolas: sobre redes de saberes. 3. ed. Petrópolis: DP et Alii, 2008. p. 15-38.

ALVES, N. Sobre a existência de currículos em redes. In: NEFFA, E.; CAVALCANTE, D. K.; MELLO, M. B. (orgs.). Educação ambiental: reflexões político-pedagógicas. Rio de Janeiro: MRA2, 2014. p. 25-49.

ALVES, N. Tecer conhecimento em rede. In: ALVES, N.; GARCIA, R. L. O sentido da escola. 6. ed. Petrópolis: DP et Alii, 2016. p. 91-100.

ALVES, N.; GARCIA, R. L. Para começo de conversa. In: ALVES, N.; GARCIA, R. L. O sentido da escola. 6. ed. Petrópolis: DP et Alii, 2016, p. 8-14.

ANDRADE, N.; CALDAS, A. N.; ALVES, N. Os movimentos necessários às pesquisas com os cotidianos: após muitas "conversas" acerca deles. In: OLIVEIRA, I. B.; PEIXOTO, L. F.; SÜSSEKIND, M. L. (orgs.). Estudos do cotidiano, currículo e formação docente: questões metodológicas, políticas e epistemológicas. Curitiba: CRV, 2019. p. 19-46.

BARROS, J. L. C.; FARIAS, I. M. S.; RODRIGUES, H. C. A.; FARIAS, M. S. Contribuição dos encontros de orientação coletiva (ECO) na formação de profissionais docentes. Areté, Manaus, v. 13, p. 1-15, 2020. Available at: http://periodicos.uea.edu. br/index.php/arete/article/view/1837. Accessed on: Dec. 8, 2021.

BRAGANÇA, I. F. S. Sobre o conceito de formação na abordagem (auto)biográfica. Educação, Porto Alegre, v. 34, n. 2, p. 157-164, 2011.

BRAGANÇA, I. F. S. Histórias de vida e formação de professores: diálogos entre Brasil e Portugal. Rio de Janeiro: EdUERJ, 2012.

BRAH, A. Diferença, diversidade, diferenciação. Cadernos Pagu, Campinas, n. 26, p. 329-276, 2006. https://doi.org/10.1590/S0104-83332006000100014

CERTEAU, M. A invenção do cotidiano: 1 . Artes de fazer. 22. ed. Petrópolis: Vozes, 2014.

CLANDININ, D.J.; CONNELLY, M. Pesquisa narrativa: experiências e história na pesquisa qualitativa. 2. ed. Uberlândia: EDUFU, 2015. 
CRUZ, G. B.; FARIAS, I. M. S.; HOBOLD, M. S. Indução profissional e o início do trabalho docente: debates e necessidades. Revista Eletrônica de Educação, São Carlos, v. 14, p. 1-15, 2020. http://doi.org/10.14244/198271994149

DELEUZE, G.; GUATTARI, F. Mil platôs. 2. ed. São Paulo: Editora 34, 2011.

DELORY-MOMBERGER, C. Formação e socialização: os ateliês biográficos de projeto. Educação e Pesquisa, São Paulo, v. 32, n. 2, p. 359-371, 2006. https://doi. org/10.1590/S1517-97022006000200011

DELORY-MOMBERGER, C. Abordagens metodológicas na pesquisa biográfica. Revista Brasileira de Educação, Rio de Janeiro, v. 17, n. 51, p. 523-740, 2012. Available at: https://www.scielo.br/pdf/rbedu/v17n51/02.pdf. Accessed on: Dec. 8, 2021.

DELORY-MOMBERGER, C. A pesquisa biográfica ou a construção compartilhada de um saber do singular. Revista Brasileira de Pesquisa (Auto)biográfica, Salvador, v. 1, n. 1, p. 133-147, 2016. https://doi.org/10.31892/rbpab2525-426X.2016.v1.n1. p133-147

EVARISTO, C. Poemas da recordação e outros movimentos. Belo Horizonte: Nandyala, 2008.

EVARISTO, C. Becos da memória. 3. ed. Rio de Janeiro: Pallas, 2017a.

EVARISTO, C. Histórias de leves enganos e parecenças. 5. ed. Rio de Janeiro: Malê, 2017b.

FERRAÇO, C. E. Eu, caçador de mim. In: GARCIA, R. L (org.). Método: pesquisa com o cotidiano. Rio de Janeiro: DP\&A, 2003. p. 157-175.

FERREIRA, L. A.; REALI, A. M. M. R. Aprendendo a ensinar e a ser professor: Contribuições e desafios de um programa de iniciação à docência para professores de Educação Física. In: REUNIÃO NACIONAL DA ASSOCIAÇÃO NACIONAL DE PÓS-GRADUAÇÃO E PESQUISA EM EDUCAÇÃO, 28., 2005, Caxambu. Anais [...]. Caxambu: ANPEd, Oct. 16-19, 2005. p. 1-17. Available at: https://anped. org.br/biblioteca/item/aprendendo-ensinar-e-ser-professor-contribuicoes-e-desafiosde-um-programa-de. Accessed on: Dec. 8, 2021.

FOUCAULT, M. Microfísica do poder. 28. ed. Rio de Janeiro: Paz e Terra, 2014.

GALVÃO, C. Narrativas em educação. Ciência e Educação, Bauru, v. 11, n. 2, p. 327345, 2005. https://doi.org/10.1590/S1516-73132005000200013

GARCIA, C. M. Formação de professores: para uma mudança educativa. Porto: Porto Editora, 1999.

GARCIA, C.M. O professor iniciante, a prática pedagógica e o sentido da experiência. Revista Brasileira de Pesquisa sobre Formação Docente, Belo Horizonte, v. 2, n. 3, p. 11-49,2010. Available at: https://revformacaodocente.com.br/index.php/rbpfp/article/ view/17. Accessed on: Dec. 8, 2021.

GONÇALVES, R. M.; RODRIGUES, A.; GARCIA, A. F. L. A conversa como princípio metodológico para pensar a pesquisa e a formação docente. In: RIBEIRO, 
T.; SOUZA, R.; SAMPAIO, C. S. Conversa como metodologia de pesquisa: por que não? Rio de Janeiro: Ayvu, 2018. p. 119-142.

HUBERMAN, M. O ciclo de vida profissional dos professores. In: NÓVOA, A. (org.). Vidas de professores. Porto: Porto Editora, 2007. p. 31-61.

JOSSO, M.C. História de vida e projeto: a história de vida como projeto e as "histórias de vida" a serviço de projetos. Educação e pesquisa, São Paulo, v. 25, n. 2, p. 11-23, 1999. https://doi.org/10.1590/S1517-97021999000200002

JOSSO, M. C. As figuras de ligação nos relatos de formação: ligações formadoras, deformadoras e transformadoras. Educação e Pesquisa, São Paulo, v. 32, n. 2, p. 373383, 2006. https://doi.org/10.1590/S1517-97022006000200012

JOSSO, M. C. A transformação de si a partir da narração de história de vida. Educação, Porto Alegre, n. 3, p. 413-438, 2007. Available at: https://wp.ufpel.edu.br/gepiem/ files/2008/09/a_tranfor2.pdf. Accessed on: Dec. 8, 2021.

LARROSA, J. Experiência e alteridade em educação. Revista Reflexão e Ação, Santa Cruz do Sul, v. 19, n. 2, p. 4-27, 2011. https://doi.org/10.17058/rea.v19i2.2444

NASCIMENTO, M. G.; FLORES, M. J. B. P.; XAVIER, D. B. Indução profissional docente: desafios e tensões no contexto de uma política pública. Currículos sem Fronteiras, S. l., v. 19, n. 1, p. 151-166, 2019. Available at: https://www. curriculosemfronteiras.org/vol19iss1articles/nascimento-flores-xavier.pdf. Accessed on: Dec. 8, 2021.

NONO, M. A. Professores iniciantes: o papel da escola em sua formação. Porto Alegre: Mediação, 2011.

NÓVOA, A.; FINGER, M. (orgs.). O método (auto)biográfico e a formação. 2. ed. Natal: EDUFRN, 2014.

OLIVEIRA, I. B.; GERALDI, J. W. Narrativas: outros conhecimentos, outras formas de expressão. In: OLIVEIRA, I. B. (org.) Narrativas: outros conhecimentos, outras formas de expressão. Petrópolis: DP et Alii, 2010. p. 13-28.

PAIVA, V. L. M. O. P. A pesquisa narrativa: uma introdução. Revista Brasileira de Linguística Aplicada, Belo Horizonte, v. 8, n. 2, 2008. Available at: https://www.scielo. br/pdf/rbla/v8n2/01.pdf. Accessed on: Dec. 8, 2021.

PÉREZ, C. L. V. Cotidiano: histórias(s), memória e narrativa - uma experiência de formação continuada de professoras alfabetizadoras. In: GARCIA, R. L. (org.). Método: pesquisa com o cotidiano. Rio de Janeiro: DP\&A, 2003. p. 97-118.

RIBEIRO, D. Lugar de fala. São Paulo: Pólen, 2019.

SANTOS, B. S. Para uma sociologia das ausências e uma sociologia das emergências. Revista Críticade Ciências Sociais, Coimbra, n. 63,p.237-280,2002.https://doi.org/10.4000/rccs.1285 SILVA, F. O. Tessituras constitutivas da abordagem (auto)biográfica como dispositivo de pesquisa qualitativa. Revista Práxis Educativa, Ponta Grossa, v. 15, n. 1, p. 1-15, 2020. https://doi.org/10.5212/PraxEduc.v.15.12960.006

SOARES, L. V.; MACHADO, P. S. "Escrevivênvias" como ferramenta metodológica na produção de conhecimento em psicologia social. Psicologia Política, Florianópolis, v. 
17, n. 39, p. 203-219, 2017. Available at: http://pepsic.bvsalud.org/scielo.php?script=sci_ abstract\&pid=S1519-549X2017000200002\&lng=pt\&nrm=iso. Accessed on:Dec. 8,2021. SÜSSEKIND, M. L.; PELEGRINI, R. Os ventos do norte não movem moinhos... In: RIBEIRO, T.; SOUZA, R.; SAMPAIO, C. S. Conversa como metodologia de pesquisa: por que não? Rio de Janeiro: Ayvu, 2018. p. 143-162.

\section{ABOUT THE AUTHORS}

Amanda Raquel Rodrigues Pessoa has a doctoral student in Education from the Universidade Estadual do Ceará (UECE). She has professor at the Instituto Federal do Ceará (IFCE).

E-mail:amandampb@hotmail.com

Maria Mikaele da Silva Cavalcante has a doctoral student in Education from the Universidade Estadual do Ceará (UECE). She has professor at the same institution.

E-mail: mikaele262009@hotmail.com

Wenderson Silva Oliveira has a doctoral student in Education from the Universidade Estadual do Ceará (UECE). He is a professor at the Rede Municipal de Educação de Sobral.

E-mail:wendoliveira@gmail.com

Isabel Maria Sabino de Farias has a doctorate in Brazilian Education from the Universidade Federal do Ceará (UFC). She is a professor at the Universidade Estadual do Ceará (UECE).

E-mail: isabelinhasabino@yahoo.com.br

Conflicts of interest: The authors declare they do not have any commercial or associative interest that represents a conflict of interests in relation to the manuscript.

Funding: The study did not receive funding.

Authors' contribution: Project Administration, Formal Analysis, Conceptualization, Writing - First Writing, Writing - Proofreading and Editing, Investigation: Pessoa, A. R. R.; Cavalcante, M. M. S.; Oliveira, W. S.; Farias, I. M. S. 